\title{
Autocontrol: A Critical Study of Achievements and Challenges in the Pursuit of Ethical Advertising through an Advertising Self-Regulation System
}

\begin{abstract}
The theory and practice of advertising self-regulation have been evolving for decades in pursuit of basic standards for advertising quality. In Spain, this discipline was put into practice in 1995, the year the Association for the Self-Regulation of Commercial Communication (Autocontrol) was created. This article aims to examine in depth the functioning of the Spanish advertising self-regulation (ASR) system, with special emphasis on the Advertising Jury, and explore to what extent some of the normative requirements of rigour, independence, and participation can be considered to have been met. The paper is based on a case study in which interviews with Autocontrol members, Jury members and consumer associations have particular bearing. The results shed light on the achievements of Autocontrol's self-regulation work and the challenges it still faces.
\end{abstract}

\section{Key words}

Advertising self-regulation, Autocontrol, consumer associations, advertising jury, advertising ethics, participation, independence.

\section{List of abbreviations}


AECOSAN: Agencia Española de Consumo, Seguridad Alimentaria y Nutrición (Spanish Agency for Consumer Affairs, Food Safety and Nutrition)

ASA: Advertising Standards Authority

ASR: Advertising Self-Regulation

AUC: Asociación de Usuarios de la Comunicación (Association of Communications Users)

CERMI: Comité Español de Representantes de Personas con Discapacidad (Spanish Committee of Representatives of People with Disabilities)

FACUA: Federación de Asociaciones de Consumidores y Usuarios de Andalucía (The Federation of Consumers and Users of Andalusia)

SRO: Self-regulatory organisation

UCCV: Unión de Consumidores de la Comunidad Valenciana (Union of Consumers of the Valencian Community)

Introduction: The practice of commercial advertising requires advertising selfregulation (ASR)

Advertising self-regulation (ASR) is an important theoretical and practical field that has been pursuing mechanisms to resolve moral problems in advertising for several decades. Spain introduced self-regulation in 1995, with the creation of the Association for the Self-Regulation of Commercial Communication (Autocontrol) (Medina and An, 2012). Over its two-year history, Autocontrol has consolidated a broad and complex structure, through which it aims to safeguard "true, legal, honest and loyal advertising" (Autocontrol). ${ }^{1}$ The association describes its work as both to assess "the ethical and 
legal correction of campaigns before their emission" and to deontologically resolve advertising-related complaints from the public and competitors.

Implementing ASR involves debates on the regulatory conditions required to promote a self-regulation system that guarantees the interests of both industry and consumers. Various ASR models claim that the advertising industry adopts an active and committed responsibility in their organisations (SRO) and their instruments (ethical codes, copy advice or pre-clearance procedures, and complaint handling), which leads to significant consumer participation and involvement (Marsden 2008). Briefly, one of the key concerns in the ASR literature is to ensure that the element of industry "self" (responsibility) remains (Fusi and Boddewyn 1986), but without resulting in a model that "confuses self-regulation with self-service" (Dacko and Hart 2005, p. 8); that is, without turning into a model "which may involve too few consumers and too many industry-selected representatives who may therefore be no more than 'token' outsiders and meek participants in the self-regulatory process" (Dacko and Hart 2005, p. 8).

In response to this concern, varying ASR models have stressed the need to consolidate rigorous, transparent and rapid procedures for process management and conflict resolution in advertising. They also highlight the importance of opening up these mechanisms to active participation from outsiders (Ginosar 2014; 2011). Concepts such as stakeholders or multi-stakeholders, self-regulation (Marsden 2008; 2011; Ginosar 2014; Hyman 2009) and ASR decentralisation (Black 2001) therefore abound in the ASR literature, along with numerous debates on the role of outsider participation in the process of regulation, self-regulation, and co-regulation (Senden 2005; Ginosar 2014; Prosser 2008; Bonzel and Risse 2010). 
The aim of this paper is to examine in depth the Spanish ASR system, with particular emphasis on its core structures, such as the Autocontrol Jury. The study asks how close certain Autocontrol key participants (both internal and external) consider the organisation is to meeting some of the ideal requirements in terms of rigour, independence and participation. In short, the study observes both the potential challenges to and improvements pending in the SRO Autocontrol.

\section{Methodology}

Case study methodology, a qualitative research technique, was used to analyse Autocontrol. The study specifically examined the organisation's key self-regulation instrument, namely, how it handles the complaints received. The case-study technique involved examining various sources and materials connected to Autocontrol's Advertising Jury. Specifically, two main source types were used:

- Reports, documents, resolutions and statutes published by Autocontrol on its website (http://www.Autocontrol.es/), together with reports published by the European Advertising Standards Alliance, EASA (http://www.easaalliance.org/), about ASR's performance at the European level.

- In-depth interviews with

o Internal actors, including 1) Jury Members and 2) Autocontrol Members. $^{2}$ 
o External actors, mainly 1) associations that filed at least one complaint in 2015 ; 2) a national consumer association, FACUA, that was previously active in Autocontrol but ended its participation in this ASR; and 3) the Observatory of Women's Image, a state-funded organisation that scrutinises advertising. ${ }^{3}$

An analysis of the extensive documentation (reports, resolutions, etc.) associated with Autocontrol was key to understanding the organisation's work and structure. The material from the interviews provided a deeper understanding of the position of the Jury Members, Autocontrol Members and consumer associations vis-à-vis the Spanish ASR system and the dynamics of the Advertising Jury. The interviews followed a semistructured model that created a space for interviewees to freely express their opinions on the study objective.

\section{Literature review}

The study of self-regulation has given rise to a broad stream of theoretical literature in the last 35 years; analyses of the role and potential of self-regulation for achieving acceptable standards of advertising quality are particularly notable (Boddewyn 1989; Harker 1998). Harker (1998) states that the various self-regulation proposals tend to fall into two groups. The first group includes descriptive proposals comparing selfregulation systems in different countries (Harker 1998; Harker and Harker 2002). These studies include Boddewyn (1989; 1992), Burleton (1982) and more recent analyses (Verbruggen, 2014; López Jiménez 2012; Medina and An 2012). The second group 
covers a series of prescriptive proposals setting out normative ideals about how ASR programmes and systems should be developed. This typology includes Armstrong and Ozanne (1983) Boddewyn (1985) and Muela-Molina and Perelló-Oliver (2014). A considerable portion of ASR studies aims to define models of governance that should (ideally) characterise these mechanisms. On the one hand, ASR studies recognise that the actors involved in taking it forward and putting it into practice (industry) must be firmly committed to the task of promoting honest advertising. On the other hand, the legitimacy of the way these mechanisms are implemented also depends on the confidence that they generate among the public and consumers. Thus, self-regulation only involves "self" insofar as it is implemented by the industry itself, while it gains respect and legitimacy so long as its commitment is perceived as real and useful by the public (Boddewyn 1989; 1992). Therefore, in this search for regulatory measures and complementary tools to guarantee the interests of industry and consumers, since the beginnings of ASR there has been a profound debate on how ethical management tools can regulate such a complex and changing environment as advertising, given that they must be designed to safeguard the (potentially conflicting) interests of advertisers and consumers.

On this question, ASR models aimed to identify several key aspects from the outset. There is a general agreement that such boards and committees are needed to promote the principles of independence and transparency, considered to be the two basic principles for gaining the public's trust and acceptance of ASR (Muela-Molina and Perelló-Oliver 2014; Armstrong and Ozanne 1983; Fusi and Boddewyn 1986). To achieve this objective, normative models require a considerable number of outsiders to be incorporated onto ethics boards and juries (García-Marzá 2004; Author 2 2007). In 
other words, incorporating people from outside the advertising industry is regarded as crucial to avoid conflicts of interest during complaint-resolution procedures (Boddewyn 1985 and 1989; Muela-Molina and Perelló-Oliver 2014; Verbruggen 2014). Similarly, the principle of independence must be upheld in order to prevent such boards from becoming mere corporate self-defence mechanisms rather than acting as impartial conflict-resolution bodies (Aznar 2005; Fernando Magarzo 2011).

Several prominent descriptive studies have specifically suggested that the public are generally sceptical about self-regulation (Ginosar 2014). One of the public's main concerns is the limited margin SROs have to avoid the potential dependence on industry interests (Dacko and Hart 2005). Some studies also note the gradual decline of consumer associations' participation in such mechanisms in favour of increased competition among the companies themselves (Harker 2000). Research also points to the generally more positive and favourable attitude of juries to complaints from companies than to those from the public, who are regarded as amateur or emotional (Harker 2000).

Some studies also reflect industry concerns about ASR, identifying the possible loss of the "self" component in the process of self-regulation if a high percentage of outsiders becomes established and leads to a predominance of external groups (Fusi and Boddewyn 1986). This aspect may discourage companies' commitment to - or interest in - these types of mechanisms.

Another increasingly important debate is the complex relationship between the mechanisms of legal or ethical self-regulation (Rotfeld 1992; Rotfeld and Taylor 2009), particularly when differentiating and comparing self-regulation, co-regulation and regulation (Senden 2005; Ginosar 2014; Prosser 2008; Bonzel and Risse 2010). In this 
complex and polysemic debate, authors use some concepts, especially self-regulation and co-regulation, with different and sometimes overlapping meanings. It has even been stated that "there is no longer a place for the dichotomy of state regulation and market self-regulation" (Ginosar 2014, p. 297). Several of the current analyses on these mechanisms claim there is "a continuum between different regulatory regimens" along which varying degrees of public and private input are established and where the different levels of stakeholder participation are distributed (Prossen 2008, p. 101). The globalisation process (which also applies to advertising messages), the growing debate on governance models, and the emergence of new advertising forms via the Internet have only heightened the importance of this discussion in recent years.

For this study, however, it is especially significant to see how the debate on the public's and consumers' role in models of ethical governance of advertising remains effective and even more consequential today. In this respect, Marsden says "the involvement of consumer-citizens at a more legitimised and consensual level than the industry ASR is still a novel approach" (2008, p. 116). This author postulates the need to consolidate a multi-stakeholder governance model (Marsden 2008; 2011). Ginosar, meanwhile, argues that the debate between self-regulation and co-regulation focuses primarily on the role consumers should play in the SRO and its importance in preventing these mechanisms from consolidating as tools to exclusively protect the interests of the industry (Ginosar 2014, p. 298). Thus, the classic debate on ASR, introduced by Boddewyn among others $(1985 ; 1988 ; 1992)$, gains importance with models that call for a multi-stakeholder or decentralised model of governance. Verbruggen's (2014) recent study on SROs in France, the Netherlands, the UK and Germany also addresses the issue of non-industry stakeholders being included on juries 
to prevent the "constant risk of [their] being captured by industry interests" (2014, p. 82). Verbruggen highlights this principle as key both for strengthening credibility and for "bolstering the enforcement capacity of SROs" (2014, p. 82).

This debate transcends the academy's interruption of various SROs. It is worth mentioning, in this regard, point 7 of Appendix 3 to the European Advertising Standards Alliance (EASA) Best Practice Self-Regulatory Model whose recommendations include the need for "A self-regulatory system [that] must be able to demonstrate that it can judge cases brought before it efficiently, professionally and above all impartially". Thus, it considers that:

They must be subject neither to the influence of the advertising industry or any particular industry sector or company, nor of government, NGOs or other interest groups. The complaints committee should have a majority of independent members and its chairman should be an independent person (EASA).

The importance of ASR systems has driven the recent expansion of studies examining the Spanish case of Autocontrol, its characteristics and its evolution (Martín and Hernández, 2011; Fernando Magarzo 2011; Patiño Alves 2007). Authors such as López-Jiménez consider the Advertising Jury as the "preferred [mechanism] for resolving advertising conflicts in Spain, even above legal tribunals" (2012, p. 58). Similarly, he concludes that the Jury is defined by "absolute autonomy and independence in its functions and formed by independent persons" (2012, p. 58). Medina and An also arrive at a similar conclusion, pointing out that "In spite of the voluntary nature of the system, the moral strength that accompanies the Jury's 
pronouncements is undeniable" (2012, p. 20). Other studies of Autocontrol have been more critical of its work. Fernández Souto, for example, notes its failure to consider any cases of sexist advertising during its first three years (2000). In a comparative study with the ASA, Muela-Molina and Perelló-Oliver conclude that Autocontrol suffers from problems on various levels, especially concerning the level of independence of its Jury members (Muela-Molina and Perelló-Oliver 2014).

However, in the literature on self-regulation in general and Autocontrol in particular, few studies examine the opinion of the actors involved in the process of selfregulation and their appreciation of whether an SRO such as Autocontrol comes anywhere near a model that effectively promotes self-regulation and meets the principles of rigour, transparency, independence and participation in its work. The present study aims to shed some light on whether consumers', Autocontrol members' and Jury members' expectations of Autocontrol self-regulatory mechanisms are satisfied. This descriptive study of the mechanism and its methods aims to integrate a range of different voices that allow us to appreciate the progress achieved over 20 years of experience as well as the potential challenges that remain pending. We also delve into the incentives or disincentives that motivate consumers and their associations to participate in these self-regulatory mechanisms.

\section{An analysis of the structure of Autocontrol and its Advertising Jury}

As mentioned above, Spain's system of self-regulation in the advertising sphere began

with Autocontrol, which emerged under the umbrella of the European Advertising Standards Alliance (EASA), a European organisation charged with promoting the 
spread of these bodies in various countries within the European Union. Autocontrol began as an initiative involving publicity, advertising and media agencies that aimed to establish the basic "rules of the game". The objective of this organisation is to ensure the industry responds to the public's demands with the goal of offering guarantees that facilitate trust and belief in advertising (Boddewyn 1992). Similarly, Autocontrol defines itself as a useful complement to, but not a replacement for, the laws that regulate advertising activity (Aznar and Catalán 2010).

Some of the aspects included in Autocontrol's goals are:

1) Promoting ethical reflection on advertising activity;

2) Developing instruments for public engagement by advertisers and publicity agencies;

3) Ethically assessing advertisers and publicity agencies; and

4) Studying complaints from various sources (consumers, competitors, other agencies, etc.) about advertisements considered to violate the advertising code of conduct.

The fourth purpose - the implementation of ethics committees or juries - has been consolidated in various theories over the years and such committees have been incorporated into self-regulation systems because of their potential to drive and consolidate these mechanisms (Aznar 2005; Fusi and Boddewyn 1986; Armstrong and Ozanne 1983). These juries receive complaints about advertisements, examine them from a deontological perspective, and write reports and resolutions scrutinising them. They have the potential to promote the principles of transparency, independence, and participation (Muela-Molina and Perelló-Oliver 2014). We now consider in detail the 
workings of Autocontrol's Advertising Jury, the levels of participation it reaches, and the profiles of the Jury members and complainants.

Autocontrol's Advertising Jury and levels of participation

Autocontrol defines its Advertising Jury as an extrajudicial body for resolving controversies and complaints about advertising material. It is, therefore, a specialised deontological advertising body; $75 \%$ of its members are appointed directly by Autocontrol's Board of Directors, whose members are mainly company representatives and some media actors (Ramos 2003; Fernando Magarzo 2011) ${ }^{4}$. Since 1999, the remaining $25 \%$ of the Jury's members have been nominated by the National Consumer Institute and the Agency for Consumer Affairs, Food Safety and Nutrition (AECOSAN). ${ }^{5}$ The incorporation of $25 \%$ of the Jury members from external sources is designed to strengthen independence and impartiality in the deliberative processes of evaluating complaints, which is the basic pillar of the consolidation and improvement of ASR in Spain (Gómez, 2001). This 25\% share was decided by the Autocontrol Board of Directors, in line with the proposal from AECOSAN (Ramos 2001). The Jury operates both as a full board (with a minimum of 6 members) and in sections (with 3 members); the sections arbitrate on complaints filed against advertisements, and the full board resolves appeals and hands down rulings. 
Participation can be evaluated through the two advertising self-regulation routes used by Autocontrol: Copy Advice and the Advertising Jury. The copy-advice process, aimed at industry members, is a non-binding ethical assessment service Autocontrol offers advertisers in advance of their campaign launches. Since 2012, this service has received 20,000 requests each year, the second-highest level of this type of activity in Europe. Copy Advice is an internal self-regulation system that companies can engage with on a voluntary basis. Consumer groups are not involved in this process, which consists of a team of 47 lawyers who advise on the possible validity of a draft advertisement in line with Autocontrol's (ethical) code, prior to its release.

The second process, the Advertising Jury's resolution of complaints and demands filed in relation to published advertisements, has increased since 2001, with the number of complaints ranging from 146 in 2010 to 305 in 2015. Nevertheless, the difference between the two types of participation provided by Autocontrol is significant compared to systems such as the Advertising Standards Authority (ASA) in the United Kingdom (which received more than 37,000 complaints in 2015), Zentrale zur Bekämpfung unlauteren Wettbewerbs (WBZ) in Germany (13,157 complaints in 2015), and Reklamombudsmannen in Sweden (Ro.) (4,985 complaints in 2015). ${ }^{6}$

These annual figures show the gradual consolidation of Autocontrol as a basic instrument for implementing ASR in Spain. A notable aspect of its preventive work is the extent to which internal actors use Autocontrol's Copy Advice service. Regarding its corrective work and participation of external actors, Autocontrol receives more than 300 complaints annually, which places it in eleventh position in the EASA ${ }^{7}$. However, in this section it falls well below the levels of participation seen in the United Kingdom, Germany, Sweden, the Netherlands, France, and Ireland. It is important to note, 
however, the difficulty of making direct comparisons between countries because of the different weight of the copy-advice and complaint-handling systems in each SRO. ASA (UK) is an outstanding example of high participation where both systems obtain a high number of applications. Meanwhile, Germany and the Netherlands traditionally focus their self-regulatory action on ex post complaint handling as a regulatory strategy, which explains the high numbers of these claims (13,157 and 3,245, respectively). France has 15,309 ex ante controls and 3,171 on ex post complaint handling. The comparisons by country are subject, therefore, to the peculiarities of each SRO (for the specific cases of France, Germany, the Netherlands, and the UK, see Verbruggen, 2014); however, it is important to remember that in Spain, the system of complaint handling, created in 1996, is considered by Autocontrol to be at the core of its selfregulatory process. The Copy Advice system, introduced in 2001, is defined as "a complement of the advertisement post-emission control system". 8

The profile of the board members

Autocontrol notes in its organisational chart that the Advertising Jury "is the key piece in our self-regulatory system". 9 At the same time, Autocontrol defines the Jury as a "specialised and independent organ for the extrajudicial resolution of controversies and complaints regarding commercial communication". ${ }^{10}$ It is therefore important to conduct a detailed examination of the Board's composition, which comprises the president, five vice-presidents, and 15 spokespeople.

An analysis of the members of the Jury in 2016 shows a high proportion of members with an academic background, particularly from the legal profession. All six 
section presidents are law professors (four in commercial law - sections 1, 2, 3 and 6, and two in administrative law - sections 4 and 5). The Jury's president and technical secretary are also professors of commercial law. Similarly, there are notable academics (albeit fewer in number) in the fields of economics and communications; for example, an economics professor is a spokesperson in section 4, and a communications professor is a spokesperson in section 2. However, the Spanish Association of Advertisers is heavily represented: four spokespeople - two in section 1 , one in section 3 , and one in section 4 - are former members of this association.

Finally, another notable aspect is that $25 \%$ of the Jury are proposed by agreement with AECOSAN. This section has strong links with state institutions: five of its six members come from state organisations, specifically the Spanish Agency for Consumer Affairs AECOSAN (1 spokesperson in section 1), the Councils of Health (2 spokespeople in sections 2 and 3), and the Council of Education, Youth and Sports (1 spokesperson in section 6). It is particularly noteworthy that no ethics professionals or academics sit on the Jury, and nor are there any representatives from consumer associations that are fully independent of the state.

The profile of complainants and type of complaints

The number of demands filed by the public (i.e., citizens' organisations or consumer associations) is important information for evaluating or measuring participation levels in this type of self-regulatory mechanism. The principle of participation acquires special relevance in such mechanisms. Autocontrol's annual reports differentiate four groups of complainants to the Advertising Board: 1) consumers or consumer associations and 
other citizens' organisations, 2) businesses or business associations, 3) cross-border complaints, and 4) administrative bodies.

Autocontrol's reports pay special attention to participation of the group "Consumers or consumer associations and other citizens' organisations" and note its increasing relevance. In $2013,81.67 \%$ of the total number of complaints came from this group. ${ }^{11}$ In $2015,79 \%$ of the complaints came from consumers and associations. ${ }^{12}$ An in-depth analysis of this information furthers our understanding of consumers' levels of participation.

Several aspects emerge from the detailed analysis of the 305 complaints lodged in 2015. Of these 305 complaints, 182 were finally discussed by the Jury (some of these complaints do not reach the Jury stage either because the complainant and the company come to a prior agreement or because the complaint is not admitted). The category of consumers and associations lodging complaints is clearly predominated by two groups. The first consists of private individuals (whose anonymity is protected throughout the process), who lodged 105 complaints, and the second is the Association of Communications Users (Asociación de Usuarios de la Comunicación, AUC), which lodged 37 complaints. That is, of the 182 complaints lodged, these two groups account for 142 (78\% of the total).

Turning exclusively to the consumer organisations that participated in Autocontrol's complaint system in 2015, in addition to the 37 complaints from the AUC, the Consumers' Union of the Valencian Community (Unión de Consumidores de la Comunidad Valenciana) lodged 6 complaints. The rest of the participating associations each lodged one complaint. These associations included the Farmers' Union (Unió de Llauradors i Ramaders), the Pedestrians' Association (Asociación A 
Pie), CGT Bankia, the Spanish Committee of Representatives of People with

Disabilities (Representantes de Personas con Discapacidad, CERMI), the General Council of Associations of Psychologists (Consejo General de Colegios Oficiales de Psicólogos), and the Web Users Association (Associación de Internautas) (see Figure 1).

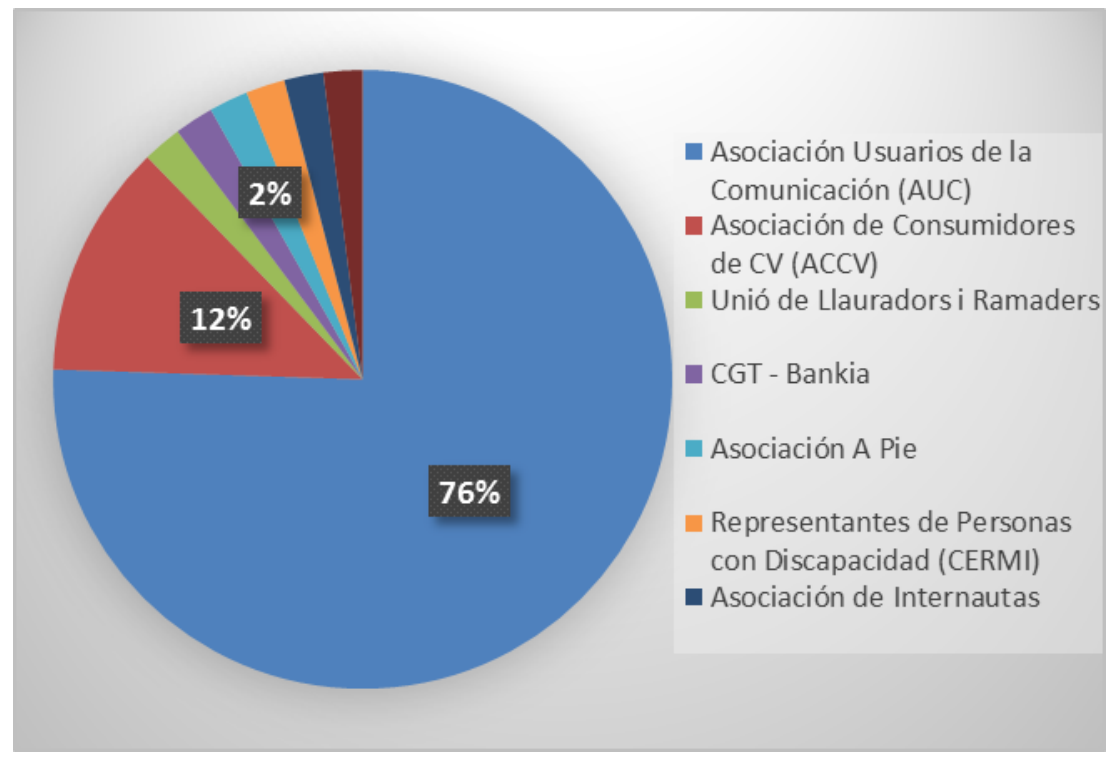

Figure 1. Percentages of complaints about advertisements exclusively from associations in 2015.

Source: The authors

These data reflect the significant concentration of complaints by two groups (individuals and AUC), and the limited range of consumer groups or associations that choose to participate in Spain's ASR process. There is also a significant absence of participation from other consumer associations that are active in the field of monitoring and controlling advertising content; this observation applies to other years as well as 2015 (Author 1, 2013). The absence of associations such as FACUA (which had 
previously been active in Autocontrol) in this process is also a key point of interest in this study.

\begin{tabular}{|c|c|c|c|c|}
\hline Type of complaints & $\begin{array}{c}\text { Favourable } \\
\text { resolution }\end{array}$ & $\begin{array}{c}\text { Partially } \\
\text { favourable } \\
\text { resolution }\end{array}$ & Dismissed & Total \\
\hline $\begin{array}{c}\text { Misleading advertising } \\
\text { (Article 14) }\end{array}$ & 21 & 4 & 47 & 72 \\
\hline $\begin{array}{c}\text { Non-compliance with } \\
\text { the law and regulations } \\
\text { (Article 2) }\end{array}$ & 25 & - & 15 & 40 \\
\hline $\begin{array}{c}\text { Discriminatory } \\
\text { advertising } \\
\text { (Article 10) }\end{array}$ & 12 & - & 6 & 6 \\
\hline $\begin{array}{c}\text { Lack of coherence } \\
\text { between the main } \\
\text { message and secondary } \\
\text { messages } \\
\text { (Article 3.3) }\end{array}$ & 5 & - & 3 & 5 \\
\hline $\begin{array}{c}\text { Denigration of other } \\
\text { companies, products, or } \\
\text { services } \\
\text { (Article 21) }\end{array}$ & 2 & - & 1 & 3 \\
\hline $\begin{array}{c}\text { Undue exposure of } \\
\text { children and adolescents } \\
\text { to inappropriate material } \\
\text { (Article 28) }\end{array}$ & 2 & & & \\
\hline
\end{tabular}

Table 1. Typology of the most common complaints based on Autocontrol's Code of Conduct (2015)

Source: The authors

Another important aspect to consider is the type of complaints received. Of the 182 complaints resolved by the Advertising Jury, 162 concerned the advertising code of conduct, predominantly complaints related to misleading advertising (72 cases) and the principle of legality (40). In this analysis, it is striking to note that 18 complaints involve cases of possibly discriminatory advertising. While this is the third reason for complaints, this advertising self-regulation mechanism receives fewer complaints than 
other specialised organisations such as the Observatory of Women's Image. This statefunded institute received 144 notices of complaint against possible discriminatory advertising in 2013 and 229 in 2014; it acted 39 times against companies (2015 data are not yet available). ${ }^{13}$

Perceptions of Jury members, Autocontrol members and associations on the Spanish ASR system

In this section we aim to build on the knowledge gained from studying reports and procedures described above by obtaining a detailed understanding of Autocontrol's workings and dynamics from the experiences of the participating actors. Varied points of view on the operations, the work and the potential for Autocontrol have emerged throughout this research. However, the study has also revealed common positions held by consumer associations, Jury members and Autocontrol members, especially in their perceptions on the process of complaint resolution. Differences have also been detected, however, leaving some questions open, especially on the principle of independence and the possible incentives (or disincentives) for consumer participation in this SRO. Information extracted from the interviews has helped us differentiate certain basic characteristics in the positions of consumer groups, Autocontrol members and Jury members vis-à-vis the Spanish SRO. We group these characteristics into three categories: a) Autocontrol's strong bridges, b) the complex principle of independence, and c) windows of opportunity to foster participation. 
Autocontrol's strong bridges: adapting procedure to respect timeframes and promote professionalism

With regard to the complaint-resolution procedure, the majority of those interviewed (Autocontrol members, Jury members and consumer associations) valued the high level of professionalism in Autocontrol's processes. Compared to other administrative or judicial methods available to formalise complaints about commercial advertisements, Autocontrol is considered to be serious, efficient and fast. All the Jury members interviewed defined the process as agile, fast, rigorous, and efficient. They also believe that cases are accompanied by ample information and that the terms of resolutions are appropriate. Consumer associations also make positive comments on the agility and professionalism involved in resolving advertising claims. Even actors that no longer use this route recognise the effectiveness of the Autocontrol process. Some of the interviewees conclude as follows:

Let's say that of all the available options, the fastest and most efficient, without a doubt, is Autocontrol, because it allows one to substantiate a procedure or resolve a complaint in a few weeks. [...] It is about acting quickly, even more so in the realm of publicity, and Autocontrol guarantees fast action (AUC).

In the same vein, the UCCV values Autocontrol's speed, defining it as "a simple, fast and agile course to resolve the incidents that can occur in an element as commonplace and basic as an advertisement." The Pedestrians' Association also expressed these opinions, noting that "communication worked, the response was reasonably fast and we 
believe that it was not just protocol". The interviewees' general perception of the various stages of the procedure is, therefore, satisfactory. Seriousness, professionalism, and speed were some of the most common evaluations provided by the interviewees.

Another point common to the interviewees' responses was the widespread defence and increasing importance of Copy Advice. Autocontrol members claim it is "very useful as an internal tool" (Autocontrol Member 2). Usefulness is explained mainly as "the sooner the advertisement message problems are detected, the sooner they are avoided" (Autocontrol Member 1). The associations generally take the same position on Copy Advice, noting the importance of preventing conflicts in advance, while supporting the strategy of raising awareness among advertisers as a fundamental step towards improving advertising. Indeed, raising awareness is deemed to be as important as punishing the advertiser for bad practices. The Observatory of Women's Image, the UCCV, and the AUC were particularly insistent on the importance of raising awareness, a process in which providing copy advice is fundamental.

In search of the complex principle of independence

As noted above, one of the key debates surrounding SROs concerns the principle of independence by guaranteeing a pluralistic and balanced representation on juries. We observed significant divergence on this point among the different groups studied.

On the one hand, Autocontrol members advocate full Jury independence. They claim that the rigorous protocol in place ensures this independence and that "in Spain, all Jury members are independent of the industry" (Autocontrol Member 1). Another Autocontrol member also stated that "the key is not that $25 \%$ of the members of the 
Jury are appointed by consumers; it is that $0 \%$ comes from industry" (Autocontrol Member 2). Autocontrol defends the relevance of Jury members being "independent, without any link to the industry and with measures to ensure their impartiality, such as, for example, having a predetermined term of office, having a number of causes for abstention and recusal, and therefore, not acting as anyone's spokespersons or representatives" (Autocontrol Member 1).

Consumer associations take a different view. There is a generalised perception among all the interviewees on the impact of the unequal representation of the Jury members. On this issue, the Farmers' Union notes that Autocontrol shows "Speed and diligence, but is then a bit distant" in a process in which "we do not feel defended nor represented, not at all." The Union compares its experience to a type of "David versus Goliath fight when trying to file a complaint about an advertisement from a multinational [company]." On the representation of plural interests in Autocontrol's mechanisms, the AUC notes that

[t]hese are bodies that necessarily - by having been created by advertisers, in which agencies participate, media agencies, the media and such - represent the point of view of the industry. [...] Autocontrol does achieve a clear separation between the claimant and the claimee, but it is true that when there is doubt, on issues that could be more open to debate, Autocontrol's tendency is, obviously, to see things more from the point of view of the industry than from the point of view of the consumers.

FACUA, the consumer association that stopped using Autocontrol after lodging several complaints in the 1990s, presents the most critical position. ${ }^{14}$ This association notes that Autocontrol is an "association of business people and we are an association of 
consumers. They value what happens in their sector and we value what consumers tell us". Their argument is as follows: "Let's say that the sector itself is judge and jury because they are the ones who make up the association of Autocontrol".

This perception of Autocontrol is not unique. Indeed, to some extent it is shared by the consumer associations or institutions we consulted. The AUC - an association that filed $70-80 \%$ of all association complaints in recent years - notes a similar idea when it asserts that,

Autocontrol is a body for resolving conflict between advertisers. Clearly, the models of voluntary regulation, self-discipline and good practices were originally designed to resolve conflicts between competitors outside court. With the philosophy that if we - meaning "we" as advertisers - carry out our work deontologically, so to speak, with a commitment to good practices, then in some way we can resolve conflicts in a friendly way, and also reach a situation in which the administration is not so interventionist, let's say, in positively regulating things.

State-funded institutions such as the Observatory of Women's Image have a similar view of Autocontrol's philosophy. Their representative noted that:

[t]he perception I have of Autocontrol is that when it was created it was really to regulate relations amongst themselves. That is, above all, disloyal competition. The idea is "don't put something that makes my product look bad next to yours in your advert" [...] the mechanism was created more for that, to favour ethical advertising among advertisers. That's why it isn't easily regarded as a mechanism for ordinary citizens. 
Given the diverse natures of Autocontrol and the associations, their different interpretations of the principle of independence are perhaps understandable, although the gap between their views is also striking. The Jury members' interpretation helps to complete the picture. The eight Jury members interviewed all stressed the transparency of the complaint-resolution process, they all noted the lack of pressure or coercion in participating on the Jury, and they all considered their experience on the Jury to be positive. Some comments were as follows: "I found a great autonomy in my own experience" (No. 1), "Autocontrol has some very good practices" (No. 7), and "we, the Jury members, enjoy absolute freedom" (No. 6). On the other hand, a careful examination of the resolutions from the 2015 Jury reveals no significant differences in the percentages of acceptance and rejection by groups. This only highlights a small deviation in the number of dismissed claims from individuals.

\begin{tabular}{|c|c|c|c|c|c|}
\hline Actor & $\begin{array}{c}\text { Favourable } \\
\text { resolution }\end{array}$ & $\begin{array}{c}\text { Partially } \\
\text { favourable } \\
\text { resolution }\end{array}$ & Dismissed & $\begin{array}{c}\text { Unfavourable } \\
\text { resolution }\end{array}$ & $\begin{array}{c}\text { No. of } \\
\text { claims }\end{array}$ \\
\hline $\begin{array}{c}\text { Private } \\
\text { Individuals }\end{array}$ & $41.18 \%$ & $\mathbf{0 . 9 8 \%}$ & $\mathbf{5 4 . 9 \%}$ & $2.9 \%$ & 105 \\
\hline Associations & $\mathbf{5 3 \%}$ & $\mathbf{2 . 2 \%}$ & $44.4 \%$ & & 49 \\
\hline Companies & $43 \%$ & $18.8 \%$ & $25 \%$ & $12.5 \%$ & 16 \\
\hline
\end{tabular}

Table 2. Complaints based on Autocontrol's Code of Conduct 2015 considering complainants and outcomes

Source: The authors

Furthermore, the Jury members interviewed generally considered that the representation and the plurality of voices were well-balanced. One interviewee argued that a greater representation of consumer associations might not be positive as they 
"adopt some approaches that are too restrictive for the practice of advertising [...] Consumers and consumer associations usually take a very extreme and belligerent position" (No. 6). This interviewee advocated maintaining the current situation with "university people" who understand "another perspective that is not so tied up with some or other approaches" (No. 6). Two Jury members (No. 3 and No. 1), however, do defend the need to deliberately broaden representation to include more social actors. Another interviewee noted that many members, even though they no longer belong to the industry "had worked in [advertising] companies and, of course, took the business perspective" (No. 3). This interviewee called for "a more diversified composition of members, social psychologists, experts on these issues, or independent persons" (No. 3). In the same vein, Jury member No. 1 stated that, "there is no space on the Jury for everyone", although he does add that including another profile from "philosophy or ethics" would be a positive move.

Ultimately, the study results reveal a clearly differentiated position between associations and members of Autocontrol on the question of Jury composition. The associations' position reflects some suspicion that the SRO mechanism in some way acts to serve the interests of Autocontrol, while the position of Autocontrol members defends the overall fairness of its procedure. The Jury members, however, generally perceive the procedure to be appropriate, although some members called for the introduction of other member profiles to enrich the process (No. 1, 2, 3). These discrepancies illustrate the difficulties involved in defining the principle of independence, which has been so widely discussed and demanded in the ASR literature. The present study allows the complexity of this debate to be considered. On this point, 
one of the Autocontrol directors considered the models proposing stakeholder-based models of governance to be negative because:

I don't think any Jury members should be representing consumers, nor should Jury members be representing the pharmaceutical industry, nor advertisers, nor agencies, nor the mass media. Jury members must be independent, impartial, and have no links to industry [...] Neither [should they] act as spokespersons or representatives for anyone. They should only represent their knowledge. [...] If the Jury members represented different interests then we would be faced with discussions of sectorial interests, not in-depth discussions on how correct or incorrect an advertisement is. (Member of Autocontrol 1)

However, consumer associations adopt a different view, arguing that it is the Board of Directors (composed mostly of businesspeople from large firms) that chooses all the Jury members, and they believe that a multi-stakeholder governance model may be able to generate greater confidence in the SRO model. On this point, the AUC argues that "although it will never be a balanced model in which all parties have the same weight, I think that the decision-making bodies or the conflict resolution body should be more balanced, perhaps with more representatives from the social sphere." FACUA defends an arbiter model with equal representation of consumers and businesspeople, pointing out that such a model "could be interesting, where from a situation of equality they decide, they resolve certain advertising conflicts", although at the same time they note that "this does not exist nor does it show any signs of existing in the short- or medium-term future." 
This study highlights the difficulty of precisely defining the term of internal and external actor (or "from industry" and "outsider") in relation to advertising juries. The long-running debate on the principle of ASR independence inevitably continues in the Spanish case. For Autocontrol members it is sufficient to establish a series of conditions (three years with no links to companies, academic profiles, 25\% appointed from AECOSAN proposals) to ensure a totally independent profile. For consumer associations, who is responsible for appointing the Jury members (mainly people from the business sector) and the limited profile type (mainly lawyers and advertising experts) usually raises suspicions about the principle of independence. For their part, Jury members value Autocontrol's good practices very positively, although some members are open to some reforms or improvements. Furthermore, the associations and several members of the Jury called for heavier penalties for breaches of the code of conduct. The associations and certain members of the Jury (especially No. 1, 2 and 3) argued that stricter penalties would help to prevent repeated breaches, would help educate companies in self-regulation, and would improve the public's perception of the independence of the association and its resolutions. However, this study has shown that there are areas in which Autocontrol could be improved other than changing the composition of the Jury or strengthening sanctions; these two key issues, linked to the self-regulation procedure, are discussed below.

Windows of opportunity to foster participation: Challenges affecting the procedure

The interviews with the actors variously involved in Autocontrol have opened up some windows of opportunity, especially concerning the hurdles to filing a complaint and the 
interpretation of the rules of conduct. We now examine the extent to which these points are regarded as key to stimulating and extending participation with the organisation.

1) The complexity of filing a complaint

On the difficulty of filing a complaint, one member of Autocontrol stated that "we offer the Spanish public a tool - an agile, quick and authoritative, independent means, free of charge, for settling complaints about any advertisement" (Autocontrol Member 2). They also claim that in procedures and resolutions "we try to be as informative as possible" (Autocontrol Member 1). However, they also acknowledged that simplifying processes is not always straightforward if rigour is to be maintained. The associations and the Jury members took different positions on this question, especially regarding the calls from associations to simplify the process of drafting a complaint about an advertisement violating the code of conduct. The associations consider the writing up of the complaint to be too formal and even "judicial" in that "it can sometimes discourage [people] from presenting the complaint" (AUC). In this regard, the Pedestrian's Association makes the following argument:

The problem we have is that we are a small association. We are more involved in day-to-day matters; and this type of thing, well the truth is that when there is a clear cause for complaint and someone gets down to the business of writing it down, then we encourage them, it gets written, and the process is put in motion. But simplifying the complaints procedure as much as possible - or making it more accessible - would really encourage participation, without a doubt. 
The Observatory of Women's Image also makes the same point:

In Autocontrol, you have to send a written complaint. [In Observatory of Women's Image complaint system] They just have to make sure we get the content. [...] They don't have to prepare a specific written report to explain their reasons. And this is also fundamental to encourage people to get involved and participate.

Therefore, although the seriousness of the procedure is recognised, there are calls to simplify the process of presenting a complaint. The Jury members interviewed, however, hold different views. Some members (No. 1, 4, 6 and 7) considered the fact that everyone, whether from the field of advertising or outside, is entitled to file a claim, free of charge, to be positive and pointed out that this indeed happens. In contrast, other interviewees (No. 2 and 3) claimed that the complexity of the process is what influences the public's ignorance about Autocontrol. The Jury members interviewed noted a general ignorance about these mechanisms among the public. One interviewee said, "because the processes are complicated and because Autocontrol [...] I think that most citizens do not know this" (No. 2). Autocontrol's own advertising campaigns do not always explain the procedure to be followed. Specifically, one interviewee from the Jury stated that, "Autocontrol has its advertising campaigns, but maybe they do not specify to the ordinary citizen that Autocontrol has a proper [complaints] channel" (No. 8). Indeed, while Autocontrol invests a significant amount in its advertising campaigns, it does not specifically mention that consumers have the right to file claims. ${ }^{15}$ 
2) Interpreting the rule: writing over its spirit?

The pursuit of rigour in Autocontrol's complaint-resolution procedures has opened up a meaningful discussion on the Spanish SRO model. Autocontrol members emphasise the importance of form and what is expressed in the codes. One member clearly illustrates this point as follows:

Autocontrol is not a court of law. Autocontrol has no potestas and for that reason it is essential to gain authority, but authority in the moral sense. Resolutions must speak for themselves. When Autocontrol asks a company to withdraw its advertisement, the company should understand why it has to do so. It may not share the opinion, but at least it must understand it [...] Resolutions must not reflect the personal tastes of one person or a small group of people. It cannot make subjective judgements. Its task is really to make a legal judgement. Does this advertisement infringe a norm [or] does it not infringe a norm? (Autocontrol member 1)

With regard to the associations, it was clear from the interviews that Autocontrol engages in a very formal judicial-type procedure. In this vein, the Pedestrian's Association notes, for example, that "[...] we received a judicial evaluation from Autocontrol, that even said we were right"; CERMI concluded, for its part, that "in law, everything is up for debate. It can be seen as black or white but they do apply a code, and they rule according to that code". Finally the Farmers' Union stated that Autocontrol: "has a very powerful legal department [...] and while we considered the advertisement to be ridiculing the image [of farmers], they take a view based on a set of 
laws and they don't see it that way, and they may be right on legal grounds, but the moral grounds remain, which, however, they don't take into account".

This perception of the process as a legal procedure is striking considering that Autocontrol's function is deontological and ethical, and that it has no legal authority. This perception could be due to the 'technical' nature of the procedure, the Jury's reports and the literal interpretation rather than considering the spirit of its own codes of conduct and industry codes. The predominance of members with a legal background may also have a bearing on this issue. On this point, the opposing views of the Jury members on how Autocontrol interprets the rules are particularly relevant. All the Jury members interviewed but one (No. 8) defined the process as strictly legal. The dissenting member stated that "perhaps I would like to see a bit more legal formality, but then my experience tells me otherwise, that things are better as they are, because even though many legal formalities are not respected, it is a very open and very easy field for everyone" (No. 8). The other members agreed, however, that Autocontrol takes a very strict line on which approaches are possible and the legal form they must take (No. 1 to 7$)$.

The Jury's conclusions on the consequences of the formal interpretations of the norm are especially relevant. Although several members claim that the current model does not prevent in-depth debate on controversial cases and that such debate is "not necessarily restricted by the rules of Autocontrol or any other regulatory apparatus" (No. 7), several members highlighted the predominance of form and strict rules concerning content and debate. Specifically, several controversial cases were mentioned that could not be addressed because "if everything fell within the law, than that was that" (No. 2). Another Jury member shared this view, claiming that in the absence of 
certain rules in the code of conduct (referring to an example of child protection) "you are left with no case, because as there is no rule nor code to be applied, it [the complaint] is dismissed. But you are left with the thought that as there is no code to base a case on, how can that possibly be grounded?" (No. 5). In a similar line, two other Jury members stated that "the emphasis on the purely legal aspects avoids [going] into controversial aspects of advertisements that might be questioned from an ethical point of view" (No. 3); this is the case when considering that "the underlying problem is that the Jury's remit is far too strictly limited to mere enforcement of regulations. When we get into controversial cases we do not introduce key aspects. We stick to a literal reading of the norm and do not introduce key issues such as the culture industry, for example" (No. 1).

This tendency may lead to Autocontrol being considered simply as a mechanism to make a literal reading and interpretation in applying the norms of behaviour, while neglecting to promote an ethical reflection on advertising activity and messages. If that is the case, actors outside the advertising industry, associations and individuals may no longer see Autocontrol as a channel of participation, reflection and discussion. Jury members and consumer associations have highlighted the importance of this issue. In addition to the debate on the importance of independence in differentiating between self-service and self-regulation, they also identify the key issue of going deeper into content by remaining open, and initiating a review of codes of ethics, especially the advertising code of conduct. In this sense, it seems important to maintain this openness, thereby allowing members of the Jury and consumer associations to participate or give their views on the rules on which the Jury must base its verdict. Opening up the debate, 
or reviewing the code of conduct, would potentially extend the channels of participation as well as increasing confidence in the Jury's resolutions.

Finally, this case study reveals that the debate on how close a process of selfregulation comes to the conditions of transparency, independence, and participation is not linked exclusively to the complex discussion on the representativeness of Jury members, but also to the application procedures and review of the norms of conduct.

\section{Conclusions}

The development of advertising self-regulatory systems (ASR), presents some interesting debates on the maturation of self-regulatory organisations (SRO) capable of maintaining rigour, independence and participation. Such organisations are capable of self-regulating in advertising, and do not turn into an instrument serving their own industry interests. The Spanish Autocontrol case shows how its self-regulatory system is working, especially in pursuing its legitimacy to prevent bad advertising ex ante through services such as Copy Advice, but also by strengthening the principles of rigour, independence and participation in its post facto mechanisms, such as the Advertising Jury. Through the design of a clear, efficient, fast and highly rigorous process, the Autocontrol Jury has earned recognition and trust in its activity both internally and externally.

However, the composition of the Jury is more problematic because the difficulties mentioned in the ASR literature review on the consideration and scope of the independence principle once again become evident. The Spanish case shows that the industry is concerned to maintain the principle of independence. However, it also 
appears that the appointment policy should be strengthened to prevent industry interests from prevailing, even indirectly, as consumers suspect. There is therefore a need to review this composition to consider including consumer associations that are independent of the state and enjoy prestige in civil society, and bringing in professionals from areas such as ethics, sociology, or social psychology.

This study has uncovered two important windows of opportunity that should be grasped to consolidate the principle of participation. The first is to make the procedure more straightforward for associations and individuals, and the second, to improve deliberative processes so that more work is done in the spirit of the rules governing selfregulation, rather than strict applications or interpretations of the code.

On the first issue, the data analysis of participation and complaints received shows an improvement in the figures and the wider range of actors using the complaints system. Although participation is stable, some specialised agencies (such as the Observatory of Women's Image) or associations also challenge companies directly without going through the Autocontrol channel, particularly over issues such as discriminatory advertising. This study shows that Autocontrol has a good window of opportunity in which to revisit the way in which complaints are presented and improve the dynamics of this process. The association's communication processes and selfadvertising could also be addressed more clearly to appeal to ordinary citizens and explicitly inform them of their right to participate in the process, so that it not only guarantees the promotion of the self-regulation process internally, but also extends it to groups of individuals and consumer associations outside the industry.

As for the second issue, one of the most important aspects observed throughout this study is the need to consolidate a self-regulation model based not only on 
implementing and reviewing respect for the deontological codes of practice in a rigorous and transparent way, but also to foster discussion and open up a process to review the norms of conduct. It should not be forgotten that promoting ethical reflection on advertising activity is one of the objectives of ASR systems such as Autocontrol - as the association itself states. However, this task is frequently neglected, since the process is limited to the application or literal interpretation of a norm and involves no in-depth discussion of what the norm involves. This problem will worsen both for the Jury and other external actors if a process to revise the codes and rules is not initiated. Therefore, throughout this study we have seen that the debate between whether a self-regulatory mechanism actually does what it says on the tin, or whether it acts to serve its own interests, is linked to elements such as rigour, transparency or the plural representativeness of interests within the juries; however, it also depends on strengthening the processes of deliberation and revision of the rules governing the selfregulating activity.

This study provides a picture of Autocontrol based on the information available on its activities and from some of its main actors (Jury members, consumer associations, and Autocontrol members). Future studies could usefully focus on the vision of companies, communication media and the general public in order to expand and extend this research. However, we believe that this initial study has uncovered some basic features to do with the characteristics, potential and possible challenges facing this modern system of self-regulation. Today, Autocontrol provides good evidence that it is consolidating a rigorous process. However, at the same time we consider that simplifying certain processes, opening up discussion, reformulating its rules of conduct, and broadening out the Jury members' profiles could deepen and enhance external 
participation in this instrument. In short, Autocontrol now has a solid foundation and a clear window of opportunity to commit to self-regulation that is not only deontological or formalistic in character, but is also critical and participatory in the pursuit of promoting honest advertising.

\section{Endnotes}

\footnotetext{
${ }^{1} \mathrm{http}: / / \mathrm{www}$. autocontrol.es/

${ }^{2}$ Interviews were conducted with the following Autocontrol and Jury members:

Former Jury Members:
}

1. Former section chairperson. 2012-2015. $\mathrm{N}^{\circ} 1$

2. Former section chairperson (appointed at the request of the National Consumer Institute). 2009-2015. № 2

3. Former section chairperson (appointed at the request of the National Consumer Institute). 2009-2015. № 3

4. Former section President 1999-2001 and President of Jury. N4 Current Members (2016 to present)

5. Section chairperson. $N^{\circ} 5$

6. Section chairperson. $\mathrm{N}^{\circ} 6$

7. Section chairperson. $\mathrm{N}^{\mathrm{o}} 7$

8. Section president. $\mathrm{N}^{\mathrm{o}} 8$

Autocontrol Members:

9. Person in charge of Copy Advice and Jury. $\mathrm{N}^{\mathrm{o}} 1$

10. Person in charge of Autocontrol. $\mathrm{N}^{\mathrm{o}} 2$

11. Autocontrol worker. $\mathrm{N}^{\mathrm{o}} 3$. 
${ }^{3}$ Interviews were conducted with the following associations and representatives:

1. Coordinator in the Area of Mediation for the Consumers' Union of the Valencian Community (Unión de Consumidores de la Comunidad Valenciana, UCCV).

2. President of the Association of Communications Users (Asociación de Usuarios de la Comunicación, AUC).

3. Delegate from the Spanish Committee of Representatives of People with Disabilities (Comité Español de Representantes de Personas con Discapacidad, CERMI) for the UN and the Human Rights Convention.

4. Cabinet member (communications) of the Farmers' Union (Unió de Llauradors i Ramaders).

5. President of the Pedestrians' Association (Asociación A Pie).

6. Speaker for The Consumers and Users Federation of Andalusia (FACUA).

7. Head of Communications and Image for the Women's Image Observatory (Observatorio de la Imagen de la Mujer).

${ }^{4}$ A list of the members of the Autocontrol Board of Directors is available at: http://www.autocontrol.es/pdfs/Junta_Directiva_Asamblea.pdf

${ }^{5}$ The National Consumer Institute merged with the Agency for Food Safety and Nutrition to form AECOSAN in 2014.

${ }^{6} \mathrm{http} / / /$ www.easa-alliance.org/Publications/Statistics/page.aspx/375

${ }^{7}$ On the levels of Autocontrol participation, see also Ignacio Cruz Roche (2015). Selfregulation of advertising in Spain. Effectiveness and efficiency of the Autocontrol Association (1995-2014). Autocontrol. DOI: 10.13140/RG.2.1.4437.8966 
${ }^{8}$ http://www.autocontrol.es/pdfs/folleto_espanol.pdf (p. 8). During the course of this work, the Autocontrol members also noted the predominant role of the Jury.

${ }^{9}$ Organisation: http://www.autocontrol.es/autocontrol_organizacion.shtml

${ }^{10}$ Article 22 of the Statutes of Autocontrol.

http://www.autocontrol.es/news/ESTATUTOS\%20_\%202014.pdf

${ }^{11} \mathrm{http}: / /$ www.autocontrol.es/pdfs/balance\%2013\%20AUTOCONTROL.pdf page 19

${ }^{12} \mathrm{http} / / /$ www.autocontrol.es/pdfs/balance_15_AUTOCONTROL.pdf page 24.

${ }^{13}$ http://www.inmujer.gob.es/observatorios/observImg/informes/docs/Informe2014.pdf (pages 16-17).

14 The various reports issued by FACUA on Autocontrol can be consulted at http://www.facua.org/es/informe.php?Id=10\&capitulo=90\&IdAmbito=13 (Consulted 9 May 2016).

${ }^{15}$ See, for instance, 2016 spot: https://www.youtube.com/watch?v=8daxE6LN7mo 


\section{References}

Armstrong, G.M., \& Ozanne, J.L. (1983). An evaluation of NAD/NARB purpose and performance. Journal of Advertising, 12( 3), 15-52.

Aznar, H. (2005). La comunicación responsable. La autorregulación de los medios. Barcelona: Ariel.

Aznar, H., \& Catalán, M. (2010). Códigos éticos de Publicidad y Marketing. Barcelona: Ariel.

Black, J. (2001). Decentring Regulation: understanding the role of regulation and selfregulation in a "post-regulatory" world. Current Legal Problems, 54 (1), 103-146.

Boddewyn, J. J. (1985). Advertising self-regulation: private government and agent of public policy. Journal of Public Policy and Marketing, 4, 129-141.

Boddewyn, J. J. (1988). Advertising Self-Regulation and Outside Participation: A Multinational Comparison. New York: Quorum Books.

Boddewyn, J. J. (1989). Advertising Self-Regulation: True Purpose and Limits. Journal of Advertising, 18(2), 19.27 .

Boddewyn, J.J. (1992). Global Perspectives on Advertising Self-Regulation. Principles and Practices in Thirty-eight Countries. Connecticut: Quorum Books..

Börzel, T. A. \& Risse T. (2010). Governance without a state: Can it work? Regulation \& Governance, 4, 113-134

Burleton, E. (1982). The Self-Regulation of Advertising in Europe. Journal of Advertising, 1, 333-344.

Dacko S. G. \& Hart, M. (2005).Critically examining theory and practice: Implications for coregulation and coregulating broadcast advertising in the United Kingdom 
Office of Communications (Ofcom). The International Journal on Media Management, 7(1\&2), 2-15

EASA (2010). Advertising Self-Regulation in Europe: An Analysis of Self-Regulatory Systems and Code of Advertising Practice (6th edn 'The Blue Book') Brussels: Poot Printers.

Fernández Souto, A. B. (2000). Los límites de la publicidad. Análisis de las resoluciones del Jurado de ética publicitaria. Revista Latina de Comunicación Social, 34, 1-7.

Fernando Magarzo, M. R. (2011). La consolidación de la autorregulación publicitaria en España:fomento normativo y reconocimiento juridisprudencial. Estudios sobre consumo, 84, 71-83.

Fusi, M. \& J. J. Boddewyn (1986). Advertising Self-Regulation by Outsiders: The Case of Italy. International Journal of Advertising, 5(2), 93-107.

García Marzá, D. (2004). Ética de la publicidad. In Conill, J. \& Gozálvez, V. (Eds.) Ética de los medios. Una apuesta por la ciudadanía audiovisual. (pp. 111-135). Barcelona: Gedisa.

Ginosar, A. (2011). The Regulation of Advertising. In Levi-Faur D. (ed) Handbook of the Politics of Regulation. (pp. 254-266). Cheltenham: Edward Elgar.

Ginosar, A. (2014). Self-Regulation of Online Advertising: A Lesson From a Failure. Policy \& Internet, 6(3), 296-314.

Gómez, J. D. (2001). La Asociación de Autocontrol de la Publicidad y la aplicación del principio de veracidad por su jurado. Estudios de Consumo, 57, 223-250. 
Harker, D. \& Harker, M. (2002). Dealing with complaints about advertising in Australia: the importance of regulatory self-discipline. International Journal of Advertising, 21(1), 23-45.

Harker, D. (1998). Achieving acceptable advertising. International Marketing Review, 15(2) 101-118.

Harker, D. (2000). Complaints about advertising: What's really happening? Qualitative Market Research, 3, 198-206.

Hyman, M. (2009) Responsible Ads: A Workable Ideal. Journal of Business Ethics, 87: $199-210$

López Jiménez, D. (2012). La publicidad ética y responsable: aproximación al fenómeno español. Entornos, 25, 53-63.

Marsden, C. T. (2008). Beyond Europe: The Internet, Regulation, and Multistakeholder Governance-Representing the Consumer Interest. Journal of Consumer Policy, $31,115-132$

Marsden, C. T. (2011). Internet Co-Regulation European Law, Regulatory Governance and Legitimacy in Cyberspace. New York: Cambridge University Press.

Martín Llaguno, M. \& Hernández Ruíz, A. (2011). El control de la comunicación comercial en un mundo globalizado. Regulación, autorregulación e hiperregulación de la publicidad". Portal de la Comunicación InCom-UAB: El portal de los estudios de comunicación, 1-19. Available at: http://www.portalcomunicacion.com/uploads/pdf/50_esp.pdf. (Consulted 15 November 2015)

Medina, Mercedes \& An, Soontae, (2012). Advertising self-regulation activity: A Comparision between Spain and US. ZER, 17(33), 13-29. 
Muela-Molina, C. \& Perelló-Oliver, S. (2014). Advertising self-regulation. A comparative analysis between the United Kingdom and Spain. Communication \& Society 27(3), 1-18.

Patiño Alves, B. (2007). La autorregulación publicitaria: especial referencia al sistema. Barcelona: Bosch.

Prosser, T. (2008). Self-regulation, Co-regulation and the Audio-Visual Media Services. Directive Journal of Consumer Policy, 31, 99-113.

Ramos, F. (2003). La publicidad contaminada. Los consumidores ante la autorregulación publicitaria. Madrid: Universitas.

Rotfeld H.J. (1992). Power and Limitations of Media Clearance Practices and Advertising Self-regulation. Journal of Public Policy \& Marketing, 11, 87-95.

Rotfeld, H. J. \& Taylor, C. R. (2009). The Advertising Regulation and Self-Regulation Issues Ripped From the Headlines With (Sometimes Missed) Opportunities for Disciplined Multidisciplinary Research. Journal of Advertising, 38(4), 5-14

Senden, L. (2005). Soft law, Self-regulation and Co-regulation in European Law: Where Do They Meet? Electronic Journal of Comparative Law, 9(1), 1-27

Verbruggen P (2014). Enforcing Transnational Private Regulation: A Comparative Analysis of Advertising and Food Safety. Cheltenham: Edward Elgar.

Author 1 (2013)

Author 2 (2007) 